DOI 10.36074/13.11.2020.v3.16

\title{
СИСТЕМНА ОРГАНІЗАЦІЯ ПЕРІОДИЧНОГО ВИДАННЯ ДЛЯ ДІТЕЙ
}

\author{
Сиромля Наталія Миколаївна \\ ORCID ID: 0000-0002-0482-1725
}

канд. фрілол. наук, доцент, доцент кафедри іноземних мов

Київський національний університет технологій та дизайну, Україна

Дитячий журнал, який є засобом масової комунікації, відіграє важливу роль у процесі отримання дитиною інформації про світ навколо. Як представник інформативно-комунікаційних джерел він має свою системно-структурну організацію, що сприяє виконанню його основних функцій.

Дитячий журнал ідентифікуємо як систему, виражену у формі надтекста, відштовхуючись від робіт Шиліної А.Г. (2012), оскільки він відповідає наступним критеріям, за Купіною Н.А. та Бітенською Г.В. [1]: 1) до фрормальних критеріїв надтекстності Дж відносимо чітко визначені хронологічні межі (проаналізовані друковані та електронні видання 2010 - 2016 рр., що видавалися на території України); 2) до концептуальних критеріїв - тематичну і модальну цілісність, можливість бути відкритою або закритою системою, в також наявність автора і адресата, структурованість (однотипні, неоднотипні видання), мовну спільність, динаміку формування та подальшого розвитку.

Зупинимося докладніше на характеристиці фрормальних критеріїв дитячого журналу.

1) дитячий журнал $є$ багаторівневою системою з ієрархічною структурою.

На першому рівні представлена сукупність всіх дитячих журналів України за певний період як надтекст. Другий рівень утворюють самостійні дитячі видання, кожне з яких представляє собою надтекст. Третій рівень - номер окремого дитячого журналу (наприклад, №№1-6 або №№1-12) як надтекст за аналізований період;

2) дитячому журналу притаманні тематична і модальна цілісність (аудиторія дітей дошкільного та молодшого шкільного віку визначає відповідний репертуар видання, наявність оцінки етичного та естетичного змісту пропонованих тем, текстів; теми окремих текстів сприяють реалізації теми номера (за наявності такої) і тематичної спрямованості видання в цілому. За характером розкриття теми дитячі журнали для дітей від 1 року до 3-х років є універсальними (немає диференціації за статевою ознакою, за інтересами), а видання для читачів від 5 років і молодшого шкільного віку і тим більше для підлітків прагнуть до гендерної диференціації (Barbi, Girl, «Дівчата»), вікової, за інтересами: для охочих навчатися весело - журнал «Веселі уроки», для любителів конструювати - «Юний моделіст-конструктор», шукачів пригод зацікавить журнал «Веселі пригоди» і Т. П., виділяються християнські журнали «Водограй» (8-13 років), «Водограйчик» (3-8 років), навчально-пізнавальні «Я вивчаю українську», «Веселий світлячок» рос.-араб. Модальна цілісність дитячого журналу виражається оцінкою етичного та естетичного змісту окремих тем і гіпертем видання $[3,4,5]$;

3) дитячий журнал має збірний образ автора (журнал створюється колективом авторів, залучаються індивідуально-авторські твори для створення номера) і конкретний тип адресата (за віком, статтю та інтересам);

4) дитячий журнал може виступати як закрита і відкрита система (дитяче видання $€$ відкритим надтекстом, якщо спостерігається його обмін енергією, 
інфрормацією з навколишнім середовищем [2], і воно представлено у вигляді окремих щорічних номерів і продовжує видаватися донині; закритим варіантом надтексту дитячий журнал може стати в результаті внутрішніх або зовнішніх змін (зміна редактора, концепції, політичні, соціально-економічні процеси, що ведуть до закриття журналу) [3, 4, 5];

5) дитячий журнал $є$ більш-менш однотипно структурованою системою (формат видання, набір рубрик, структура текстів окремого номеру);

6) дитячий журнал має мовну спільність для певної вікової аудиторії (у виданнях для наймолодшої аудиторії не використовується мовна гра, іншомовні вкраплення, в журналах для школярів і підлітків виявлено використання мовної гри, оказіоналізмів, одиниць сленгової лексики, англіцизмів та т.п.);

7) дитячий журнал динамічно розвивається (динаміка розвитку видання, пов'язана з економічною, політичною, історичною ситуацією в країні, науковотехнічним прогресом: поява сайтів журналів «Мурзилка», «Веселі картинки», «Пізнайко» та ін., оригінальних мережевих видань $[3,4,5]$.

Таким чином, наші дослідження свідчать про те, що дитячий журнал $\epsilon$ ідеальною системою, яка складена з об'єктів - понять або ідей, пов'язаних як одне ціле, це складна єдність, динаміка якого фрормується структурою системи, її складом і внутрішньою організацією.

\section{Список використаних джерел:}

1. Купина Н. А., \& Битенская Г. В. (1994). Сверхтекст и его разновидности. Купина Н.А., Матвеева Т.В. (ред.) Человек-Текст-Культура (с. 214-233). Екатеринбург: ИРРО.

2. Князева Е.Н., \& Курдюмов С.П. (1994). Законы эволюции и самоорганизации сложных систем. Москва: Наука.

3. Украинские детские журналы. Обзор. Вилучено 3: http://uti-puti.com.ua/view_articles.php?id=411

4. Сайти дитячих журналів і газет. Вилучено з http://ditky.at.ua/dir/novini_ta_zmi/10-1-2 